Winter 2004

\title{
Amazigh Activism and the Moroccan State
}

\author{
Paul Silverstein \\ David Crawford \\ Fairfield University, dcrawford@fairfield.edu
}

Follow this and additional works at: https://digitalcommons.fairfield.edu/sociologyandanthropologyfacultypubs

Copyright 2004 Middle East Report

\section{Peer Reviewed}

\section{Repository Citation}

Silverstein, Paul and Crawford, David, "Amazigh Activism and the Moroccan State" (2004). Sociology \& Anthropology Faculty Publications. 9.

https://digitalcommons.fairfield.edu/sociologyandanthropology-facultypubs/9

\section{Published Citation}

Crawford, David L. and Silverstein, Paul. (2004). "Amazigh Activism and the Moroccan State" in The Middle East Report, issue 233. Ed. Chris Toensing. Pp. 44-48. Washington, D.C.: MERIP 2004.

This item has been accepted for inclusion in DigitalCommons@Fairfield by an authorized administrator of DigitalCommons@Fairfield. It is brought to you by DigitalCommons@Fairfield with permission from the rightsholder(s) and is protected by copyright and/or related rights. You are free to use this item in any way that is permitted by the copyright and related rights legislation that applies to your use. For other uses, you need to obtain permission from the rights-holder(s) directly, unless additional rights are indicated by a Creative Commons license in the record and/or on the work itself. For more information, please contact digitalcommons@fairfield.edu. 


\section{Amazigh Activism and the Mopoccan State Paul Silverstein and David Crawtopd}

W hen primary school students in the major Berberspeaking regions of Morocco returned to class in September 2004, for the first time ever they were required to study Berber (Tamazight) language. The mandatory language classes in the Rif, the Middle Atlas, the High Atlas and the Sous Valley represent the first significant policy change implemented by the Royal Institute of the Amazigh [Berber] Culture, a government body established by King Mohammed VI on October 17, 200I, following through on a promise made in July of that year on the second anniversary of his ascension to the Moroccan throne.

This royal edict, or dabir, represents a dramatic reversal of legal discrimination against Imazighen (Berbers) and an explicit attempt to reclaim Berberness as "a principal element of national culture, as a cultural heritage present across all stages of Moroccan history and civilization." Since Moroccan nationalist discourse has tended to emphasize links to the high culture of Arab-Islamic civilization, and in particular the royal patriline leading back to the Prophet Muhammad, the dabir indicates a shift in, or at least an amendment to, the official national imaginary. Instead of posing Berber culture as a challenge to national unity, the king promoted embracing it as a necessary step in his project for a "democratic and modernist society."

The dabir and subsequent establishment of the Royal Institute, known in Morocco by its French name, l'Institut Royal de la Culture Amazighe, or IRCAM, are partly the result of domestic and international pressure to create a transparent regime of social justice and human rights. These initiatives met many of the demands made over the last 20 years by the various cultural associations, student groups and political movements associated with the diffuse Amazigh Cultural Movement (MCA), and increasingly, the United States and other allies have heralded Morocco's reform efforts as a success story. The shifts in the national imaginary also signal a creative response of the Moroccan state to transnational Islamist politics, a response that weds the rhetoric of ethno-national identity to a universalist discourse of democracy. The dabir thus serves to transform Amazigh militants into allies of the state in Morocco's local "war on terror."

Nonetheless, the creation of IRCAM and its interventions to promote Berber art and culture in the spheres of media and education have neither gone unopposed within the ranks

Paul Silverstein, an editor of Middle East Report, teaches anthropology at Reed College. David Crawford teaches anthropology at Fairfield University. of Amazigh activists, nor been recognized as anything other than distant state "politics" by the mass of Berbers in the countryside. Activists have challenged every decision leading up to curricular reform, as they suspect that the institute is simply a state attempt to coopt the Amazigh opposition and turn living Berber culture into static folklore. In spite of the dahir, Amazigh militants have been detained repeatedly by police and threatened with charges of treason for taking part in street demonstrations for Berber land rights and the naming of Tamazight as a constitutionally recognized national language of Morocco. Such a climate of perceived repression is accepted with evident apathy by most Berbers, but has ironically radicalized some Amazigh militants into the ideal supporters of George W. Bush's global war on terror. Viewing the Moroccan state as a bastion of Arab nationalism, the latter have taken increasingly anti-Arab positions that go so far as to deny the legitimacy of the Palestinian cause and support the US invasion of Iraq, positions that have led to conflict with Islamist and Marxist opposition groups, as well as with elements of Moroccan state security. Rather than assuring national unity, the establishment of IRCAM has arguably exacerbated the fragmentation of not only the Amazigh movement, but also Moroccan oppositional politics in general.

\section{Amazigh Militancy and State Cooptation}

Berber speakers are estimated to make up 40 percent of the Moroccan population. ${ }^{1}$ In spite of the fact that Muslim Berber dynasties controlled Morocco at various points since the arrival of Islam, the conflation of Arabic language, Islamic legitimacy and Arab ethnicity has nonetheless proved to be an enduring feature of Moroccan consciousness. Viewing Berber cultural identity as largely a colonial invention designed to fragment the Moroccan nation, the 1950s nationalist movement-under the direction of the Istiqlal Party, consisting primarily of Fezbased Francophone elites-sought to forge a univocal identity for Moroccans along the ideological lines of an Arab nationalism imported primarily from Egypt and Lebanon. Until the IRCAM dahir, the monarchy, deriving its temporal authority from its religious lineage, had repeatedly underwritten such an Arabo-Islamist ideology that has entailed the adoption of Arabic as the official and national language of Morocco.

This version of Moroccan nationalism has faced severe opposition, particularly from the Berberophone left. Already in the 1960s, Berber students and intellectuals in Rabat and Paris, 
under the aegis of the Association Marocaine de la Recherche et des Echanges Culturels (AMREC), began collecting and disseminating Berber folklore and oral traditions. In the 1970s, these activities became more politicized, with the growth of several cultural associations, the Université d'Eté d'Agadir and Tamaynunt, who actively promoted Berber identity. ${ }^{2}$ However, it was the Algerian-Kabyle student uprisings of April 1980 (known internationally as the Berber Spring) and the subsequent solidification of a transnational Berber Cultural Movement (MCB) that galvanized Moroccan Amazigh ethnolinguistic militancy into a public movement, with conferences and a published journal, Amazigh.

While this movement was largely repressed during the 1980s, there has been an immense resurgence within the last ten years. In 1994, seven teachers, most of whom were members of the Amazigh association Tilelli (Freedom) from the southeastern oasis town of Goulmima, were arrested after their participation in a May Day parade in nearby Errachidia for carrying banners written in Tifinagh. Police held the seven for several weeks, after which the courts sentenced three of them to prison terms and large fines. The three were later released on appeal and the charges subsequently dropped after the case received widespread international publicity and offers of aid. Responding to the outcry, the Moroccan government promised reforms, with Prime Minister Abdellatif Fillali opening channels for Berber-language programming in the national broadcast media and the late King Hassan II declaring in his August 1994 Throne Day speech that Amazigh "dialects" were "one of the components of the authenticity of our history" and should in theory be taught in state schools. Since this speech, Amazigh associations and newspapers (now numbering in double digits) have flourished throughout Morocco. In a variety of charters and international declarations, Amazigh militants have promulgated a redefinition of Morocco on the basis of its pre-colonial and pre-Islamic Berber heritage, and have sought political change to preserve Berber culture and language as a "human right."

To address these demands the state created IRCAM. The institute's 33-member administrative council was recruited through the Amazigh associational structure, with an apparent attempt to garner an equal representation of activists from the three major Berberophone regions in the Rif, the Middle Atlas and the Sous. Amazigh militants with technical training and advanced degrees have likewise been incorporated into the institute's seven research centers charged with linguistic standardization, pedagogical development, artistic expression, anthropological analysis, historical preservation, translation and media promotion, and communication. Salaries offered to researchers are superior to what could be earned in the state school system or even as a teacher in the burgeoning private education market.

Boasting an estimated annual budget of $\$$ Ioo million, the institute is temporarily housed in a hyper-modern commercial center located in the posh Rabat neighborhood of Hayy

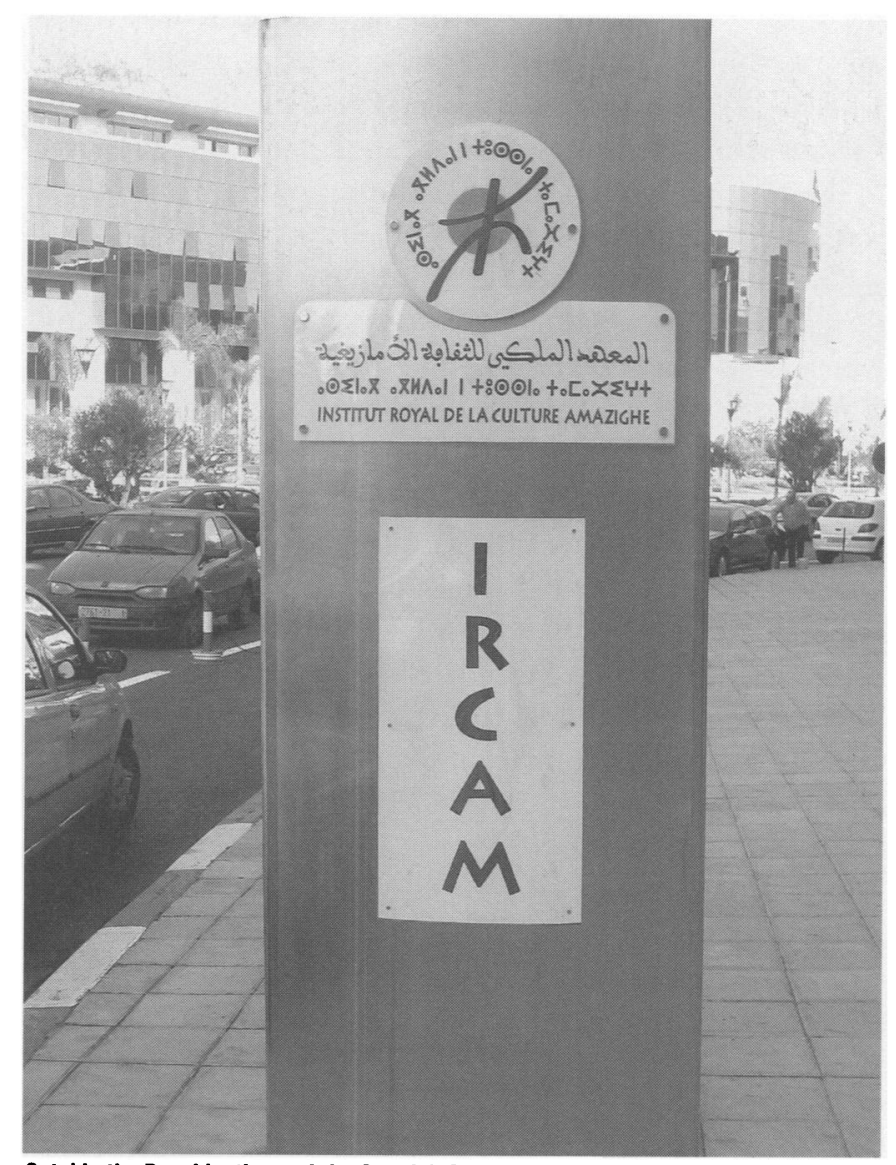

Outside the Royal Institute of the Amazigh Cutture, Rabat. PAUL SILVERSTEIN

Riyadh and owned by the Group Ominum North Africa, the largest Moroccan enterprise controlled by the royal family. The IRCAM is building its own state-of-the-art facility whose monumental design incorporates a number of recognizable Amazigh motifs. The administrative and research centers are fabulously equipped with the latest technology, and the library has actively acquired printed and audiovisual materials. Regardless of any actual policies put in place by IRCAM, such expenditures constitute a bold public relations gambit, performing the commitment to transparent cultural qua human rights demanded by US and European interlocutors who hold the purse strings for development aid and could recommend admittance into the European Union. Morocco's recent positive dialogues with the UN and the State Department attest to the gambit's initial success. ${ }^{3}$

\section{Oppositional Politics}

The repercussions of the establishment of IRCAM for the Amazigh movement and Moroccan oppositional politics are harder to judge. On the one hand, the institute has succeeded in bringing together Amazigh militants from different associations and ideological factions. On the eve of the dahir, three distinct and opposed groups could be identified: the "royalist" Mouvement National Populaire and its allied associations, drawing their major support from the Middle Atlas; 
the "historical," "moderate" AMREC based in Rabat, whose membership is essentially the urban intelligentsia; and the "left-wing" Tamaynunt/Université d'Eté d'Agadir, which drew its base primarily from the Sous. Among militants employed in the research centers, these divisions proved untenable and soon largely broke down.

On the other hand, the establishment of IRCAM has effectively split the movement into two macro-factions: those who support the institute's agenda, and those who oppose it, either on principle or out of resentment for not having been recruited into it. Activists who joined the institute attest to the difficulty of the choice, of their foreknowledge that they would lose credibility in the eyes of their peers, but in the end they believed that they had a better chance of facilitating change by working within the system. Today they are often denounced by some of their former comrades as having been makhzenisé (or even ircamisé), of literally having been transformed into de facto representatives of the state (al-makhzen). Opponents are outspoken in their belief that the institute works in the interest of global forces of Arab nationalism, publicly declaiming that "IRCAM = IRCAN" ("filth" in the Tashelhit dialect).

Dissenters point to several recent institute decisions as evidence of IRCAM's hidden "divide and conquer" strategy with respect to the transnational Amazigh movement. In the first place, they object to the official adoption of the $\mathrm{Ti}$ finagh script as the standard means to write Berber language in Morocco. The 2003 decision was highly contested within IRCAM, decided by only a handful of votes according to one of the members of the administrative council, and derived in large part from members' fears of threatened Islamist reprisals should the Latin script have been adopted. Although officially couched in a language of cultural authenticity, the adoption of Tifinagh was, in the end, a political compromise. Nevertheless, many Amazigh militants view the decision as a thinly veiled ploy to separate Moroccan Berbers from those in Kabylia or diaspora France where Berber language (Tamazight) is written in the Latin alphabet. They also understand the production of separate textbooks in the three major Moroccan Berber dialects (Tarifit, Tamazight and Tashelhit), instead of the standard Tamazight developed by Paris-based linguists, as part of an effort not only to divide the international Berber community, but to fragment the national one as well.

Although peripheral Amazigh activists are happy to benefit from IRCAM's largesse (in terms of invitations to conferences or offers to publish their poetry), they criticize it for monopolizing the public expression of Berber culture at the expense of smaller associations and grassroots organizational efforts. With IRCAM's huge budget and ability to attract additional militants to Rabat, public funds and activist support for local efforts at social development and cultural preservation have proven more and more scarce, and many Amazigh associations are closing their doors. With their privileged access to media outlets, IRCAM and the Rabat-based Centre Tarik bin Zyad run by Hassan Aourid, the king's official spokesman (porte-parole), have indeed become the primary centers for the representation of Berberness. A potent example of this monopolization is the Imilchil festival, 
the annual High Atlas moussem where young Berber men and women marry supposedly outside of familial negotiations. Promoted by the Moroccan state over the last ten years as a tourist destination, the festival had become an opportunity for local cultural associations to support their yearly activities by vending High Atlas Berber arts and crafts, or by being paid by the state for their musical and dance performances. In 2004, however, the moussem was taken over by Aourid's center, which promoted it as an "Amazigh" event, bringing in performance groups from across Morocco, Algeria, France and Canada. Local associations were excluded from the organization and enactment of the festival, a symbolic and financial blow that has elicited much criticism.

In this sense, IRCAM and its sister Rabat organizations have further radicalized a number of Amazigh militants in the Moroccan hinterland and exacerbated a long-standing urban-rural divide. In newspaper editorials, on e-mail list-serves, through photocopied tracts and during periodic public demonstrations, these critics have adopted an increasingly extremist discourse in the face of what they see as a persistence of the dominance of an Arabized Fez elite. They bemoan the lack of Berber representation in the upper echelons of the government and claim the right to create an Amazigh political party. They decry the economic marginalization of Berberophone rural areas and call for sustained state investment in infrastructure. They demand the protection of tribal lands from ongoing expropriation by state agents and private speculators, identifying land, like language, as an essential part of Berber identity. Finally, they promulgate the recognition of Tamazight in the constitution as a national and official language of Morocco, and therefore a mandatory subject in all schools, not just those attended by mostly Berberophone students. The current linguistic educational situation, they insist, will only ensure the demise of Berber language and the further marginalization of rural Berberophones.

The radical nature of these demands has brought these Amazigh militants into occasional confrontation with state authorities. On August 29, 200I, Moroccan national security officials brought into custody two of the members of Tilelli who had previously been arrested in 1994 and informed them that they would be rearrested and tried for treason for any future participation in demonstrations. In March 2004, five other Tilelli members were similarly threatened with arrest for taking part in an unauthorized sit-in to protest the state's cession of five hectares of tribal land to a private investor. More poignantly, on April 21, 2004, during a march organized to commemorate the twenty-fourth anniversary of the Berber Spring, four student militants from the University of Agadir branch of the MCA were detained, interrogated and severely beaten by police. In every case, association leaders used the Amazigh press and the virtual organization of Amazigh militancy on e-mail list-serves and websites to call rapid attention to the confrontations and elicit support. In several cases, militants used their ties to members of IRCAM

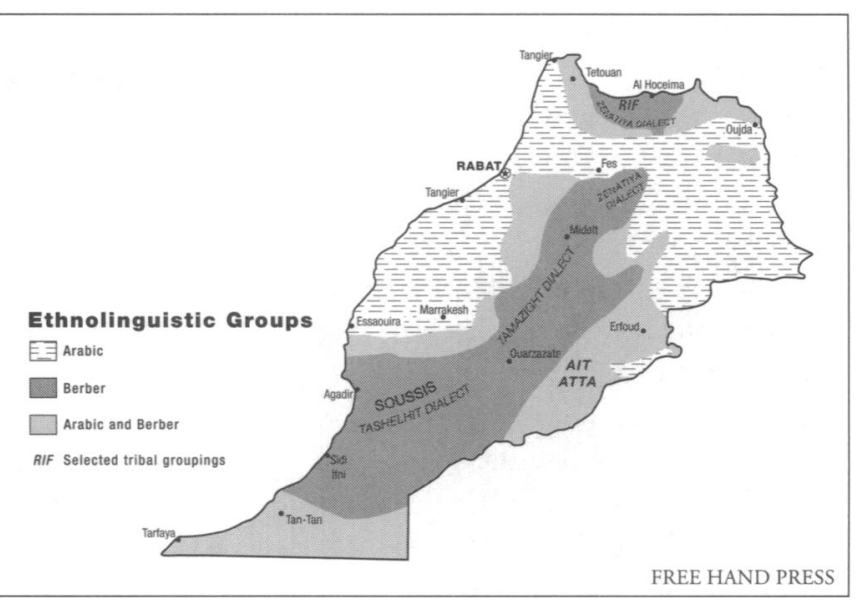

and high-profile Rabat-based human rights organizations to lift the threat of legal repercussions.

\section{"Arabo-Islamic Imperialism"}

In addition to maintaining a state of low-intensity conflict between the Amazigh movement and the state, peripheral Amazigh extremism has furthered a rift within Moroccan oppositional politics that, ironically, has benefited the state. While the Moroccan left-along with the vast majority of the Moroccan population, Arab- and Berberophone alike-has been vehemently opposed to the US-led war on terror and occupation of Iraq, Amazigh militants tend to see Saddam Hussein and Osama bin Laden as part of the same scourge of "Arabo-Islamic imperialism" that threatens their cultural particularity. They are proud to have been among the first to offer their public condolences to the US ambassador in the days immediately after the September II, 20OI attacks. They later came out strongly in favor of the invasion of Iraq and were beside themselves with joy over news of the capture of Saddam. In Goulmima, residents have even joked that Bush must be himself an Aït Murghad (the local Berber tribe), going as far as creating a fictive genealogy to incorporate him as their symbolic brother. Indeed, their only reproach for Bush was why he had not already taken the battle to Saddam's "AraboBaathist" neighbors in Syria.

In like fashion, these peripheral Amazigh militants have increasingly refused to voice active support for the Palestinian struggle, viewing the hegemonic pro-Palestinian politics of the Moroccan left as a poignant example of imposed Arab nationalism. This unwillingness to criticize Israeli state actions stems in part from a larger philo-Semitic discourse adopted by many Amazigh activists. While by no means the agents of the Israeli state that Islamists occasionally accuse them of being, some Amazigh militants have actively sought to reconcile Jewish and Berber populations, and have publicly advocated a normalization of relations with Israel. They generally see in the Israelis a direct parallel for the Amazigh struggle: a minority people who succeeded in codifying and saving a threatened 


\section{EDITOR'S PICKS}

American Friends Service Committee. When the Rain Returns: Toward Justice and Reconciliation in Palestine and Israel (Philadelphia: American Friends Service Committee, 2004).

Cohen, Stephen P. The Idea of Pakistan (Washington, DC: Brookings Institution Press, 2004).

Collins, John. Occupied by Memory: The Intifada Generation and the Palestinian State of Emergency (New York: New York University Press, 2004).

Eppel, Michael. Iraq from Monarchy to Tyranny (Gainesville, FL: University Press of Florida, 2004).

Grodzinsky, Yosef. In the Shadow of the Holocaust:
The Struggle Between Jews and Zionists in the Aftermath of World War II (Monroe, ME: Common Courage Press, 2004).

Human Rights Watch, Morocco: Human Rights at a Crossroads (New York, October 2004).

International Crisis Group, Iraq: Can Local Governance Save Central Government? (Amman/Brussels, October 2004).

International Crisis Group, Who Governs the West Bank? Palestinian Adminstration Under Israeli Occupation (Amman/Brussels, September 2004)

Al-Khafaji, Isam. Tormented Births: Passages to Modernity in Europe and the Middle East (London: I. B. Tauris, 2004).
Klare, Michael. Blood and Oil: The Dangers and Consequences of America's Growing Dependency on Imported Petroleum (New York: Metropolitan Books, 2004).

Lockman, Zachary. Contending Visions of the Middle East: The History and Politics of Orientalism (Cambridge: Cambridge University Press, 2004).

Shelley, Toby. Endgame in the Western Sahara (London: Zed Books, 2004)

Swisher, Clayton. The Truth About Camp David (New York: Nation Books, 2004).

Warschawski, Michel. Toward an Open Tomb: The Crisis of Israeli Society (New York: Monthly Review Press, 2004). language, gained territorial autonomy and is currently threatened by a surrounding Arab majority.

Such pro-Americanism and philoSemitism have brought many Amazigh militants into direct conflict with the very leftist groups in which the majority of them cut their political teeth in the university student unions during the 1970s and 1980s. Accusing the Moroccan left of latent Arab nationalism, a number of Amazigh associations refused to participate in - and even actively opposed - the various anti-war rallies and May Day demonstrations organized in the past several years. The disagreement over the Palestinian question has even occasionally broken out into violent confrontations between the two movements. In what the Amazigh press decried as "pseudo-Marxist terrorism" (al-irhab al-mutamarks), on December 23, 2003 members of the Marxist Basiste student movement brutally knifed a handful of Amazigh student union members at the University of Errachidia when the latter refused to participate in an exam strike in solidarity with the intifada. Although the details of the attack remain contestedwith some claiming that the conflict was as racially as ideologically motivated-it does point to the ways in which Moroccan oppositional politics have become violently fragmented in the years since the establishment of IRCAM.

\section{Unintended Consequences}

The creation of IRCAM has helped elimi- nate some of the main forms of official linguistic and cultural discrimination in the Moroccan legal and educational systems. It serves as a visible symbol of an emerging, state-sanctioned civil society intended to please international observers. While a number of Amazigh activists have embraced the institute's potential to foster education in the native tongue for rural children and to promote Berber art and culture in urban public spaces, others critique these overtures as cultural cooptation by the state designed ultimately to divide the transnational Amazigh movement. One recalls that the late King Hassan II was skilled at manipulating ethnic politics, "playing different factions off against one another, thereby gathering decisive power into his own hands." 4 Perhaps, the Moroccan monarchy requires divisive ethnic politics in order to function.

But beyond its fragmenting effects on opposition politics, the establishment of IRCAM underlines how, increasingly, cultural and linguistic expression has been articulated as a fundamental human right in Morocco and internationally. If, on an international level, the protection of cultural rights has been postulated as a precondition for entry into the ranks of democracies, on a domestic level it has been upheld as a means of fostering national unity. But, ironically, the IRCAM dahir seems to fetishize Berberness in a way that is reminiscent of the protectorate-era "Berber dahir" that inflamed Moroccan nationalist passion in 1930. While the new dahir does not outline separate
Islamic laws for urban people (understood to be Arabs) and customary, "tribal" laws for rural people (understood to be Berbers), it does pave the way for different educational formats in different parts of the kingdom. The areas where Berber is to be the language of instruction are in large part the countryside rather than the city, making rural and urban education even more separate-and even less equal. In protesting these clearly divisive policies, Moroccan Amazigh militants have turned to their transnational interlocutors, soliciting diaspora Berber associations and international bodies supporting autochthonous peoples' rights. Rather than an imagined modernist national unity, the establishment of IRCAM may serve to underwrite regional entrenchment and a form of opposition politics that seeks to bypass the nation-state, not strengthen it.

\section{Endnotes}

1 This figure is likely decreasing given the progressive Arabization of the previously Francophone education system and the increase in migration to Arabophone cities in the north of the country. See Salem Chaker, Imazighen ass-a [Berberes dans le Maghreb contemporain] (Algiers: Editions Bouchene, 1989) for statistics on estimated numbers of Berber speakers in North Africa.

2 For histories of Amazigh activism in Morocco, see Chaker, op cit.; David Crawford, "Morocco's Invisible Imazighen," Journal of North African Studies $7 /$ I (2002); and Bruce MaddyWeitzman, "Contested Identities: Berbers, 'Berberism' and the State in North Africa," Journal of North African Studies $6 / 3$ (200I).

3 The State Department country report (February 25, 2004) is online at http://www.state.gov/g/drl/rls/hrrpt/2003/27934 $\mathrm{htm}$. See also Human Rights Watch's cautiously positive assessment, Morocco: Human Rights at a Crossroads (October 2004).

4 Edward H. Thomas, "The Politics of Language in Former Colonial Lands: A Comparative Look at North Africa and Central Asia," Journal of North African Studies 4/I (1999). See also Abdallah Hammoudi, Master and Disciple: The Cultural Foundations of Moroccan Authoritaianism (Chicago: University of Chicago Press, 1997) 